\title{
Covid-19 Enfeksiyonunun ARDS komplikasyonunda IL-10 ve IL-10 (-1082G/A) Gen Varyasyonunun Potansiyel Rollerinin İncelenmesi
}

\author{
Nevra ALKANLI ${ }^{1}$, Arzu AY \\ 1 Haliç Üniversitesi Tıp Fakültesi, Biyofizik Anabilim Dalı, İstanbul. \\ 2 Trakya Üniversitesi Tıp Fakültesi, Biyofizik Anabilim Dalı, Edirne.
}

\section{ÖZET}

COVID-19 yeni koronavirüs hastalığı olarak bilinmektedir ve COVID-19 enfeksiyonundan kaynaklanan komplikasyonlar yaş, cinsiyet ve komorbiditeler gibi çeșitli faktörlere bağlı olarak değișmektedir. Tüm yaş gruplarını etkileyebilen COVID-19 enfeksiyonu etkilenen popülasyonların bireysel özelliklerine bağı olarak doğrulanmış vakaların bir kısmında ciddi rahatsızlık ve ölüm nedeni olarak ortaya çıkabilmektedir Bu enfeksiyon özellikle yaşlı bireylerde ve hipertansiyon, diabetes mellitus, astım gibi komorbiditelere sahip kişilerde daha şiddetli seyretmektedir. Ancak COVID-19 enfeksiyonunun oldukça genç olan bireylerde de görülebileceği bildirilmiştir. Bu yüzden doku proteinlerinin ekspresyon düzeyleri gibi intrinsik faktörlerin yanısıra, genetik varyasyonlar gibi genetik faktörler de enfeksiyon patogenezine katkıda bulunabilmektedir. COVID-19 hastalarının yarısından fazlasında en sık görülen komplikasyonlardan biri yoğun bakım tedavisi gerektiren ARDS (Akut Solunum Sıkıntısı Sendromu) dir. COVID-19'da viral enfeksiyona yanıt olarak İnterlökin-10 (IL-10) gibi sitokinler salınmaktadır. COVID-19 enfeksiyonu sırasında gelișen sitokin firtınası kontrolsüz inflamasyona neden olmaktadır. Böylece çoklu organ yetmezlikleri gelişebilmekte ve ARDS ile ilişkili sendromlar indüklenebilmektedir. Sitokin firtınası COVID-19 hastalarında anlamlı derecede artmış IL10 düzeyleri ile ilişsilendirilmiștir. ARDS patogenezinde inflamasyon önemli bir belirteçtir. Proinflamatuar ve antiinflamatuar sitokinler arasındaki dengesizlik sonucunda ARDS gelişebilmektedir. IL-10 geninin promotör bölgelerindeki genetik varyasyonlar sonucunda IL-10 mRNA ve protein düzeylerinde değişiklikler ortaya çıkmaktadır. IL-10'un patolojik proinflamatuar işlevi engelleyerek COVID-19 enfeksiyonundaki mortalitenin azalmasına katkı sağlayabileceği düşünülmektedir. ARDS gelişen COVID-19 hastalarında IL-10 geninin promotör bölgesinde tanımlanan IL-10 (-1082G/A) gen varyasyonu genotip dağılımlarına göre IL-10 ekspresyon düzeylerinin belirlenmesi, ARDS'nin patolojik mekanizmalarının daha iyi anlaşılabilmesi ve ARDS'ye yönelik terapötik stratejilerin geliştirilebilmesi bakımından oldukça önemlidir. Bu derlemede COVID-19 enfeksiyonunda gelişen ARDS komplikasyonunda IL-10 ve IL-10 (-1082G/A) gen varyasyonlarının rolünün incelenmesi amaçlanmıştır.

Anahtar Kelimeler: COVID-19. Akut Solunum Sıkıntısı Sendromu. İnterlökin. IL-10. Genetik Varyasyon.

Examination of the Potential Roles of IL-10 and IL-10 (-1082G/A) Gene Variation in ARDS Complication of COVID-19 Infection ARDS Complication of COVID-19 and IL-10 Gene Variation

\begin{abstract}
COVID-19 is known as the novel coronavirus disease and complications proceed from COVID-19 infection vary depending on various factors such as age, gender and comorbidities. COVID-19 infection which can affect all age groups may occur as a cause of serious illness and death in some of the confirmed cases, depending on the individual characteristics of the affected populations. Therefore, besides intrinsic factors such as the expression levels of tissue proteins, genetic factors such as genetic variations may also contribute to the pathogenesis of the infection. One of the most common complications in COVID-19 patients is ARDS (Acute Respiratory Distress Syndrome). In COVID-19, cytokines such as IL-10 are released in response to viral infection. Cytokine storm that develops during COVID-19 infection causes uncontrolled inflammation. Thus, multiple organ failure can develop and ARDS-related syndromes can be induced. Cytokine storm has been associated with significantly increased IL-10 levels in COVID-19 patients. Changes occur in IL-10 mRNA and protein levels as a result of genetic variations in the promoter regions of the IL-10 gene. It is thought that IL-10 can contribute to the reduction of mortality in COVID-19 infection by preventing pathological proinflammatory function. Determining IL-10 expression levels according to IL-10 (-1082G/A) gene variation genotype distributions defined in the promoter region of IL-10 gene in COVID-19 patients with ARDS very important in terms of better understanding of the pathological mechanisms and developing of therapeutic strategies. In this review, it is aimed to examine the role of IL-10 and IL-10 (-1082G/A) gene variation in ARDS complication of COVID-19 infection.
\end{abstract}

Key Words: COVID-19. Acute Respiratory Distress Syndrome. Interleukin. IL-10. Genetic Variation.

Gelis Tarihi: 08.Mayıs.2021

Kabul Tarihi: 06.Eylül.2021
Dr. Öğr. Üyesi Nevra ALKANLI

T.C. Haliç Üniversitesi Tıp Fakültesi,

Biyofizik AD. İstanbul

Tel.: 05465851841

E-posta:nevraalkanli@halic.edu.tr
Yazarların ORCID ID Bilgisi:

Nevra ALKANLI: 0000-0002-3745-8838

Arzu AY: 0000-0002-8412-091X 
SARS-CoV-2'nin neden olduğu COVID-19 dünya çapında sosyal ve ekonomik sorunlara yol açan önemli bir halk sağlığı sorunudur. COVID-19 patogenezine bakıldığında enfeksiyon virüsün çeşitli dokularda ekprese edilen Anjiyotensin Dönüştürücü Enzim 2 (ACE 2) reseptörlerine bağlanması ile başlamakta ve böylece aşırı immün yanıt tetiklenmektedir. Proinflamatuar sitokinlerin aşırı üretimi sonucunda ortaya çıkan sitokin firtınası COVID-19 enfeksiyonunun şiddetli progresyonu ve organ hasarı ile ilişkilendirilmiştir. COVID-19 enfeksiyonunun patofizyolojik mekanizması tam olarak açıklanamamıştır, ancak inflamasyon ile ilişkili yolaklardaki genlerde ortaya çıkan genetik varyasyonların enfeksiyonun seyri ve ciddiyetine olan etkileri araştırılmaktadır. Yaşlı yetişkinlerde ve komorbiditeleri olan kişilerde COVID-19 enfeksiyonu daha şiddetli seyretmektedir. COVID-19 enfeksiyonu ateş, öksürük, nefes darlığı, halsizlik, kas ağrıları, tat ve koku bozuklukları, ishal, baş ağrısı gibi çeşitli semptomlar ile karakterizedir. Ayrıca enfeksiyon sirasında ARDS, tromboembolik durumlar, kardiyovasküler rahatsızlıklar ve bunlara bağlı olarak ikincil enfeksiyonlar gibi komplikasyonlar ortaya çıkabilmektedir ${ }^{1}$.

Genetik varyasyonlar ile yapılmış çalışmaların sonuçları popülasyonlar arasında farklılıklar göstermektedir ${ }^{2}$. İmmünite ve inflamatuar yanıtta etkili olan IL-10 (-1082G/A) gen varyasyonu gibi IL-10 gen varyasyonları ve ARDS gelişimi arasında anlamlı ilişskiler olduğu düşünülmektedir ${ }^{3}$. Antiinflamatuar bir sitokin olarak bilinen IL-10, diğer proinflamatuar sitokinlerin modülasyonunda da önemli rol oynamaktadır. IL-10 (-1082G/A) gen varyasyonu sonucunda ortaya çıkan guanin / adenin baz yer değiştirmesi, IL-10 düzeylerinin düzenlenmesinde etkilidir ${ }^{2}$. COVID-19 komplikasyonlarından biri olan ARDS'de IL-10 (-1082G/A) gen varyasyonunun GG homozigot genotipi daha düşük hastalık şiddeti ile ilişkilendirilmiştir ${ }^{3}$.

COVID-19 enfeksiyonu ile ilişkili ARDS gelişiminde IL-10'un hastalıktaki olası rolü ile ARDS ve IL-10 ($1082 \mathrm{G} / \mathrm{A})$ gen varyasyonu arasındaki ilişkinin daha iyi anlaşılabilmesi, hastalık ile ilgili terapötik stratejilerin geliştirilebilmesi için farklı popülasyonlar ile daha kapsamlı çalışmaların gerçekleştirilmesi gerekmektedir. Bu derlemenin amac1, COVID-19 enfeksiyonunun komplikasyonlarından biri olan ARDS'nin fizyopatolojisi hakkında genel bilgi verilmesinin yanısıra; IL10'un ve bu genin promotör bölgesinde tanımlanan IL-10 (-1082G/A) gen varyasyonunun hastalık gelişimindeki olası rolünün incelenmesidir.

\section{Koronavirüsler}

Koronavirüsler insanlarda ve hayvanlarda hastalığa neden olabilen geniş bir virüs ailesidir. İlk olarak 2002 yılında SARS-CoV tanımlanmıştır ve bu koronavirüs şiddetli akut solunum sendromuna (SARS) neden olmuştur. Daha sonra 2012 yılında MERS-CoV ve
2019 yılında SARS-CoV-2 koronavirüsleri tanımlanmıştır. Bu koronavirüslerden MERS-CoV Orta Doğu Solunum Sendromuna (MERS), SARS-CoV-2 ise COVID-19 enfeksiyonuna neden olmuştur. İnsanları enfekte edebilen yedi koronavirüs arasında olan HCoV-NL63, HCoV-229E, HCoV-OC43 ve HKU1 koronavirüsleri üst solunum yolu enfeksiyonlarının yaklaşık \%10-\%30'undan sorumludur. SARS-CoV, MERS-CoV, SARS-CoV-2 olarak bilinen, yüksek mortalite ve morbidite oranları ile ilişkilendirilen diğer koronavirüsler ise ARDS gibi ciddi solunum yolu enfeksiyonlarına yol açabilmektedirler ${ }^{4}$.

Coronaviridae ailesine ait olan koronavirüsler alfa $(\alpha)$, beta $(\beta)$, gama $(\gamma)$ ve sigma $(\delta)$ olmak üzere dört grupta sinıflandirılmaktadirlar. SARS-CoV-2, RNA genomunu tutan $\mathrm{N}$ (nükleokapsid) proteini ile $\mathrm{S}$ (spike), $\mathrm{E}$ (zarf) ve $\mathrm{M}$ (zar) proteinlerinden oluşmaktadır. Bu proteinlerden S proteini ACE 2 reseptörünü tanımakta ve ona bağlanmaktadır. ACE 2 yolağı virüsün girişinde ve akciğer alveoler epitel hücrelerine replikasyonda önemli rol oynamaktadır ${ }^{5}$.

\section{COVID-19 Patogenezi}

SARS-CoV-2 koronavirüsünden kaynaklanan bir enfeksiyon olarak ortaya çıkan COVID-19, dünya çapında hızla yayılan önemli bir halk sağlığı sorunu ve küresel pandemi olarak bilinmektedir. COVID-19 enfeksiyonu gözlenen bireylerin bazılarında asemptomatik ya da hafif semptomlar gözlenmesine rağmen, bu enfeksiyondan etkilenen ve progresif solunum yetmezliği, ölümcül pnömoni ile karakterize olan şiddetli vakalar da görülebilmektedir. COVID-19'un klinik yönetiminin belirlenmesi için genetik özelliklerin yanında hastalık sonuçlarını etkileyebilecek olan gen ve protein ekspresyon modellerinin incelenmesi de önemlidir. SARS-CoV-2 enfeksiyonu solunum yolu hastalığı olarak bilinmekle birlikte bu enfeksiyonun sistemik patogeneze ve birçok organın etkilenmesine neden olarak ölüme yol açabileceği bildirilmiştir. COVID-19 enfeksiyonunun bulaşması ile ilgili belirsizlikler olmasına rağmen bu enfeksiyonun doğrudan temas, solunum damlacıkları ve viral partiküllerin yutulması yoluyla bulaşabileceği düşünülmektedir. Bireye iletilen virüs, S proteininin ACE 2 reseptörü ile etkileşimi yoluyla insan hücrelerine doğrudan girebilmektedir'. ACE 2'nin insan alveoler epitel hücrelerinde, dil ve oral mukoza epitel hücrelerinde, lökositler, kan damarları, kalp, böbrek, bağırsak gibi diğer hücrelerde yüksek oranda eksprese edildiği bilinmektedir ${ }^{2,6,7}$.

Tip II transmembran serin proteaz (TMPRSS2), ACE 2 reseptörüne bağlanmaktadır ve bu proteolitik bir süreçtir. $\mathrm{Bu}$ süreçte $\mathrm{S}$ proteininin aktive olmasıyla hücreye viral giriş gerçekleşmektedir. İmmünglobulin süper ailesine ait olan transmembran glikoprotein olarak bilinen CD147 epitel hücrelerde bulunmaktadır. SARS-CoV tarafindan bağlanan diğer bir reseptör 


\section{Covid-19 ARDS Komplikasyonu ve IL-10 Gen Varyasyonu}

olarak bilinen bu glikoprotein inflamatuar dokularda, enfekte olmuş hücrelerde yüksek düzeyde eksprese edilmektedir ${ }^{1}$.

COVID-19 patogenezi oldukça karmaşıktır ve ilk olarak viral replikasyon üst solunum yolunun mukozal epitelinde gerçekleşmektedir ${ }^{6,8}$. Bu durumda enfeksiyon asemptomatik olarak gelişmektedir. COVID-19 patogenezi esas olarak SARS-CoV-2'nin akciğerlerde ACE 2 reseptörlerine bağlanması yoluyla alt solunum yollarında tetiklenen inflamasyon ile karakterizedir. COVID-19 enfeksiyonu gelişen hastalardan bazılarında solunum semptomları dişında çoklu organ tutulumlarına yol açabilen hasarlar da ortaya çıkabilmekte$\operatorname{dir}^{6,9-11}$.

COVID-19 enfeksiyonunun erken aşamalarında TMPRSS2, katepsin B ve L (Cat B/L) proteinleri gibi proteinlerin ekspresyon profilleri ve interferon gama üretimi enfeksiyonun sonucunu belirleyebilecek olan önemli yolaklardır ${ }^{12,13}$. Enfeksiyonun ilerleyen aşamalarında ise hücresel immün yanıtlar önemli belirleyiciler haline gelmektedir. Bu yolaklarda ortaya çıkan interferon gama üretimindeki ve hücre migrasyonu veya aktivasyonundaki dengesizlikler, inflamatuar mediyatörlerin salınımı ve immün hücrelerde farklılıklara neden olabilen kötü hastalık prognozuna yol açabilmektedir. Akciğer enfeksiyonu ile birlikte yoğun inflamatuar yanıt gelişmektedir. Hafif ya da orta dereceli enfeksiyon durumunda normal lenfosit-nötrofil oranları ve $\mathrm{CD} 8+, \mathrm{CD} 4+$ hücrelerinde yükselme gösterilmiștir. Enfeksiyonun şiddetli olması durumunda yüksek nötrofil-lenfosit oranları, düşük CD4+ sayıları, düzenleyici $\mathrm{T}$ hücrelerinde eksiklikler gözlenmekte$\operatorname{dir}^{14-19}$. Sistemik inflamatuar düzeyler COVID-19 enfeksiyonunun şiddeti ile ilişkilendirilmiştir. Hafif COVID-19 enfeksiyonunda düşük sitokin ve kemokin düzeyleri belirlenmiştir. Şiddetli COVID-19 enfeksiyonunda ise yüksek seviyelerde IL-10 düzeyleri tespit edilmiștir $^{16,17}$

COVID-19 enfeksiyonunda koroner kalp hastalıkları, kalp yetmezliği, serebrovasküler hastalıklar ve kardiyovasküler hastalıklar gibi çeşitli komplikasyonlar da ortaya çıkmaktadır. Artmış sempatik stimülasyon, hiperkoagulabilite ve inflamasyonun bu komplikasyonlara katkıda bulunduğu düşünülmektedir ${ }^{20-22}$. Ayrıca COVID-19 enfeksiyonunun diğer belirleyici bir komplikasyonu da böbrek yetmezliğidir. Bu durum virüsün doğrudan bir etkisi olabileceği gibi enfeksiyonun ardından gözlenen hipoksi sonucunda ortaya ç1kan bir durum da olabilir. Önceden var olan kardiyovasküler hastalıklar ve böbrek hastalıkları COVID-19 enfeksiyonu için önemli risk faktörleri olarak bildirilmiştir. Bu yüzden bu risk faktörlerinin enfeksiyonun şiddetlenmesine katkıda bulunabileceği düşünülmektedir. Bunların dışında gastrointestinal sistem bulguları da COVID-19 enfeksiyonu ile ilişkilendirilmiştir. COVID-19 enfeksiyonunda karın ağrısı, iștahsızlık, karaciğer fonksiyonlarında bozukluklar, diyare, bulan- t1 ve kusma gibi çeşitli bulgular gözlenmektedir. Şiddetli COVID-19 enfeksiyonundan ölen hastalarda yapılmış ölüm sonrası analizlerde gastrointestinal mukozal dejenerasyon, ince bağırsaklarda dilatasyon ve stenoz gibi çeşitli değişiklikler tespit edilmiştir. Ayrıca bu enfeksiyondan ölen hastaların mide, duodenal ve rektal epitel hücrelerinde viral proteinler saptanmıştır. COVID-19 enfeksiyonunun gastrointestinal semptomlarının SARS-CoV-2 virüsünün gastrointestinal hücreler ile doğrudan etkileşiminden kaynaklanabileceği düşünülmektedir. COVID-19 enfeksiyonu sonucunda testis dokusu da etkilenebilmektedir ${ }^{7,23-27}$.

\section{Sitokinler ve IL-10 Gen Varyasyonlarl}

Stimülasyon sonucunda immün hücreler tarafindan sitokinler üretilmektedir. Sitokinler spesifik reseptörlere bağlanarak hedef hücrelerin aktivasyonunun, proliferasyonunun ve farklılaşmasının upregüle edilmesinde, immün reaksiyonların düzenlenmesinde ve diğer sitokinlerin üretiminin indüklenebilmesinde veya inhibe edilebilmesinde önemli rol oynamaktadırlar. Sitokinler işlevlerine göre proinflamatuar sitokinler ve antiinflamatuar sitokinler olmak üzere iki grupta sinıflandirılmaktadırlar. Proinflamatuar ve antiinflamatuar sitokinler arasında ortaya çıkan dengesizlikler sonucunda immün sistemin düzgün çalışması engellenmektedir $^{28}$ (Figür 1). Sitokin genlerindeki dengesizlikler sitokin genlerinde ortaya çıkan genetik varyasyonlar ile ilişkilendirilmiştir. Bu sitokinlerden biri olan IL-10 önemli bir immünoregülatör sitokindir ve esas olarak makrofajlar tarafindan salgılanmaktadır. IL-10 makrofajlar dışında ayrıca Th1 ve Th2 lenfositleri, dendritik hücreler, monositler ve mast hücreleri, sitotoksik $\mathrm{T}$ hücreleri, B lenfositleri tarafindan da salgilanmaktadır ${ }^{29,30}$.

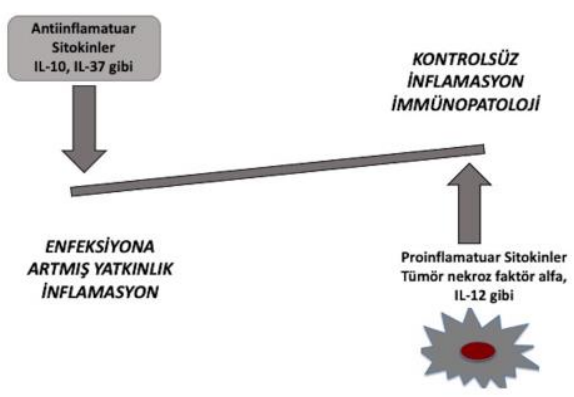

Figür 1 .

Proinflamatuar ve antiinflamatuar sitokinler arasindaki denge

IL-10 aktivitesi IL-10 reseptörü (IL-10R) aracılığıyla gerçekleşmektedir. IL-10'un IL-1, IL-6, IL-8, IL-12 gibi diğer sitokinlerin ekspresyonlarını upregüle ettiği bildirilmiștir. B hücrelerinde apoptozu önleyebilen IL10, hücre proliferasyonunun arttırılmasında ve immünglobulin sınıf değişimlerinde etkili bir immünomodülatördür. 4 intron ve 5 ekson içeren IL-10 geni 
immünomodülatör pleiotropik bir sitokindir ve kromozom 1q31-32 üzerinde lokalizedir. IL-10 geninde tanımlanmış olan genetik varyasyonlar arasında IL-10 (-1082G/A), IL-10 (-892C/T) ve IL-10 (-592C/A) gen varyasyonları bulunmaktadır $^{31-34}$ (Figür 2). IL-10 (-1082G/A) gen varyasyonu genotip dağılımlarının belirlenmesinde Polimeraz Zincir Reaksiyonu (PZR) yöntemi uygulanmaktadır. PZR yönteminde $G$ alel spesifik primeri, A alel spesifik primeri, kontrol fragment primeri ve reverse primer kullanılmaktadır. PZR yöntemi kullanılarak IL-10 (-1082G/A) gen varyasyonu genotip dağılımları GG ve AA homozigot genotipleri ile GA heterozigot genotipi olarak belirlenmektedir. PZR yönteminde kullanılan primer dizileri ve PZR koşulları Tablo I ve Tablo II'de sunulmuştur ${ }^{35}$ (Figür 3)

Tablo I. IL-10 (-1082G/A) Gen Varyasyonunu için Primer Dizileri

\begin{tabular}{|ll|}
\hline \multicolumn{2}{|c|}{ IL-10 (-1082G/A) gen varyasyonu için primer dizileri } \\
\hline G-Alel Spesifik Primeri & F1: 5'-ACTACTAAGGCTTCTTTGGGAG-3' \\
\hline A-Alel Spesifik Primeri & F2: 5'-ACTACTAAGGCTTCTTTGGAA-3' \\
\hline Forward Kontrol Primeri & FK: 5'-GACTCCAGCCACAGAAGCT-3' \\
\hline Reverse Primer & RP: 5'-GGATGTGTTCCAGGCTCCT-3' \\
\hline
\end{tabular}

G: Guanin; A: Adenin; F1: Forward 1; F2: Forward 2; FK: Forward Kontrol; RP: Reverse Primer

Tablo II. IL-10 (-1082G/A) Gen Varyasyonu için PZR Koşulları

$\left.\begin{array}{|c|c|}\hline \text { IL-10 } & \text { Başlangıç } 95^{\circ} \mathrm{C} \text { 'de } 5 \text { dakika } \\ \text { (-1082G/A) } & 94^{\circ} \mathrm{C} \text { 'de } 60 \text { saniye } \\ \begin{array}{c}\text { Gen Varyas- } \\ \text { yonu }\end{array} & 50^{\circ} \mathrm{C} \text { 'de } 30 \text { saniye } 30 \text { döngü } \\ & 72^{\circ} \mathrm{C} \text { 'de } 30 \text { saniye }\end{array}\right\}$

PZR: Polimeraz Zincir Reaksiyonu

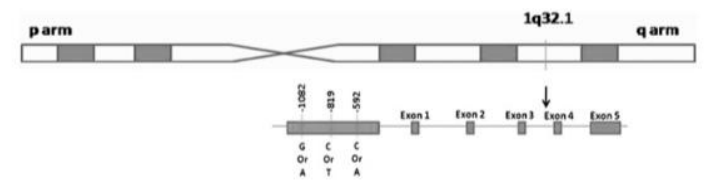

Figür 2.

IL-10 geni ve IL-10 gen varyasyonlart

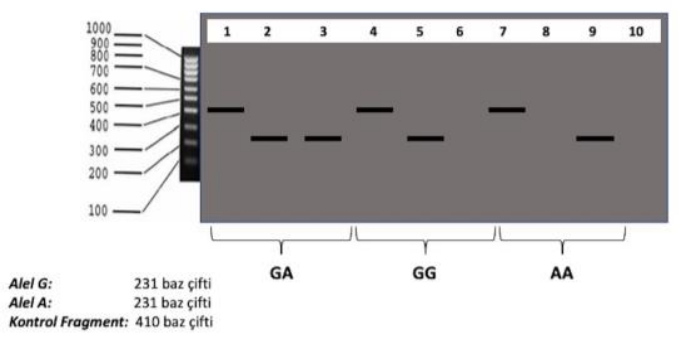

Figür 3.

PZR sonucunda elde edilen IL-10 (-1082G/A) gen varyasyonlarl genotip dă̆llımlart
IL-10 gen varyasyonları astım, sistemik lupus eritematozus, sedef hastalığı, romatoid artrit, inflamatuar bağırsak hastalıkları, tüberküloz, pnömoni gibi çeşitli hastalıkların patofizyolojisinde ve klinik seyirlerinde önemli rol oynamaktadırlar. Endojen ve eksojen faktörler tarafindan IL-10 üretimi tetiklenebilmektedir ve IL-10 salınımı genin promotör bölgesindeki microsatellites olarak bilinen dinükleotid tekrarlarına ve genin promotör bölgesindeki tek nükleotid gen varyasyonlarına bağlıdır. IL-10'un immün sistem düzenlenmesindeki rolü ve IL-10 ekspresyonunun polimorfik regülasyonları birlikte değerlendirildiğinde hastalık patofizyolojisi hakkında önemli bilgiler sağlanabilir ${ }^{31-33}$.

\section{COVID-19 Enfeksiyonunda Sitokin Firtınasl ve IL- 10'un Potansiyel Rolü}

COVID-19 enfeksiyonu tüm dünyada yaklaşı 1.1 milyondan fazla ölüme ve 42 milyondan fazla vakaya neden olmuştur. Şiddetli COVID-19 enfeksiyonunda sitokin salınım sendromu olarak da adlandırılan patolojik bir durum gelişmektedir ve bu durum çok sayıda inflamatuar sitokin ve kemokinlerin hızlı bir şekilde uzun süreli olarak sistemik yükselmesi ile karakterizedir. Sitokin salınım sendromu sonucunda organ yetmezliği ve ölüme kadar ilerleyebilen ARDS ilişkili hemofagositik sendrom indüklenebilmektedir ${ }^{36}$ (Figür 4). COVID-19 enfeksiyonu süresince gelişebilen sitokin firtınasının karakteristik bir özelliği, ağır ve kritik COVID-19 hastalarında IL-10 düzeylerindeki dramatik yükselmedir ${ }^{37}$. Yoğun bakım tedavisi gören COVID-19 hastalarında yoğun bakım tedavisi görmeyen hastalara kıyasla anlamlı derecede daha yüksek periferik IL-10 konsantrasyonu belirlenmiştir ${ }^{1}$. IL-10 düzeyleri IL-16 gibi diğer sitokinler ve CRP gibi inflamatuar belirteçler ile ilişkilendirilmiștir. IL-10'un COVID-19 enfeksiyonunun şiddeti ile ilişkili önemli bir immün belirteç olduğu düşünülmektedir. IL-10 ekpresyonlarındaki artış COVID-19 enfeksiyonunun kötü sonuçları ile ilişkilendirilmiştir ${ }^{37}$.

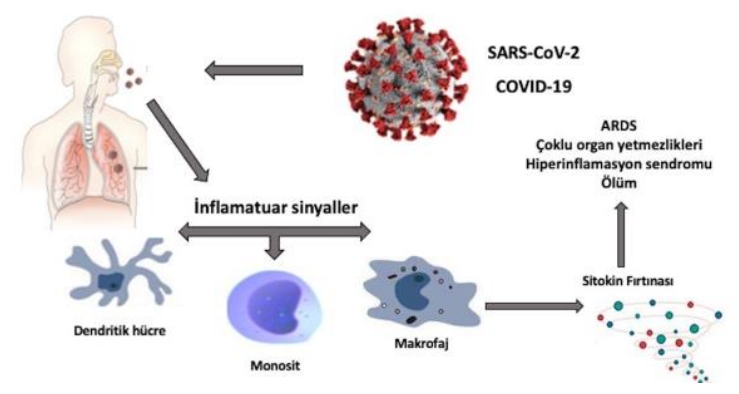

Figür 4.

COVID-19 Enfeksiyonunda Sitokin Fırtınasl ve IL10'un Potansiyel Rolü

Bir meta-analiz çalışmasında IL-6 ve IL-10'un COVID-19 şiddetinin tahmin edilebilmesinde önemli faktörler olduğu belirlenmiştir. Serum IL-10 düzeyleri COVID-19 enfeksiyonununda yükselmektedir ve bu 


\section{Covid-19 ARDS Komplikasyonu ve IL-10 Gen Varyasyonu}

durum klinik açıdan önemlidir ${ }^{38}$. Antiinflamatuar veya immün inhibitör mekanizma olarak düşünülen artmış IL-10 düzeyleri, proinflamatuar sitokinlerin negatif geri besleme döngüsü sonucunda birikmesi yoluyla uyarılmaktadır. COVID-19 enfeksiyonunda gelişen bir komplikasyon olan ARDS tedavisinde immünoregülatör ve antifibrotik etkiler gösterebilen rekombinant IL10 önemli bir terapötik faktör olarak önerilmiştir ${ }^{39-41}$. Buna karşın, COVID-19 enfeksiyonunda IL-10 düzeylerindeki anormal yükselmenin COVID-19 şiddetinin belirlenmesinde patolojik bir rol oynayabileceği de düşünülmektedir. IL-10 genellikle immünosupresif ve antiinflamatuar bir sitokin olarak bilinmesine rağmen otoimmün hastalıklar, çeşitli kanser türleri gibi hastal1klarda immün sistemi aktive edebilen proinflamatuar bir sitokin olarak da düşünülebilmektedir. Rekombinant IL-10 proinflamatuar etki göstererek immün sistemi aktive edebilmekte ve böylece inflamasyonun artışında etkili olabilmektedir. Şiddetli pnömoni ve proinflamatuar mediyatörler aracılığıyla ortaya çıkan ciddi organ hasarı COVID-19 hastalarında mortalite ile ilişkilendirilmiştir. IL-10, COVID-19 enfeksiyonunda mortalitenin azaltılmasında potansiyel bir rol oynayabilmektedir. Şiddetli COVID-19 enfeksiyonu olan hastalarda anormal derecede yüksek IL-10 düzeyleri gözlenmektedir. IL-10'un COVID-19 patogenezinde proinflamatuar etki göstererek immün aktive edici bir rol oynayabileceği bildirilmiştir. Ayrıca şiddetli COVID-19 enfeksiyonu olan hastaların periferik kanlarında IL-4, IL-7, IL-18, IFN-gama, TNF-alfa gibi inflamatuar sitokinlerin ve çeşitli kemokinlerin arttığ belirlenmiştir $^{37}$. Şiddetli COVID-19 enfeksiyonu olan hastalarda periferik CD8+T hücre sayısında toplam bir azalma gözlenmektedir. COVID-19 enfeksiyonunun ilerleyen dönemlerinde hastaların periferik kanlarındaki CD8+T hücrelerinin arttığı tespit edilmiştir ${ }^{14}$. Bu durumun aşırı aktivasyon ve proliferasyon aracılığıyla serum IL-10 düzeylerindeki artma ile ilişkili olabileceği düşünülmektedir ${ }^{37}$. Yüksek sistemik IL-10 düzeylerine sahip olan şiddetli COVID-19 hastalarında IL10 düzeylerinin hastalığın progresyonunda önemli rol oynayabileceği düşünülmektedir. COVID-19 enfeksiyonu ile ilişkili immünopatolojik yolak önemlidir ${ }^{42}$.

Akciğerlerde başlangıç aşamasında COVID-19 enfeksiyonunda IL-10 erken indüksiyonunun gerçekleşmesi diğer proinflamatuar mediyatörlerin yol açtığı inflamasyona karşı önemli bir faktördür. Endojen IL-10 üretimindeki artış, sitokin firtınasının diğer mediyatörlerinin üretiminin uyarılmasında etkili olarak immün aktive edebilen bir proinflamatuar faktör olarak etki gösterebilir. Ayrıca IL-10, ciddi COVID-19 hastalarında viral sepsise bağlı olarak daha yüksek hiperinflamasyonuna neden olabilmektedir ${ }^{43,44}$. IL-10 sitotoksik efektör CD8+T hücrelerinde artışa neden olmaktadır ve böylece COVID-19 hastalarında adaptif immünite hiperaktivasyonu gerçekleşmektedir. $\mathrm{Bu}$ da COVID-19 enfeksiyonunun şiddetindeki artış ile ilişkilendirilmiştir. IL-10 ölümcül bir immünopatolojik süreçte önemli rol oynayabilmektedir. COVID-19 hastalarında sistemik inflamatuar sitokin üretimini indükleyebilen IL-10, T hücre aktivasyonu ve proliferasyonunu da uyarabilen bir sitokindir. IL-10'un patolojik proinflamatuar işlevi engelleme yoluyla COVID19 enfeksiyonundaki mortalitenin azalmasına katk1 sağlayabileceği düşünülmektedir. Ciddi COVID-19 enfeksiyonu gelişen hastalarda IL-10 aktivitesinin engellenebilmesinde zaman oldukça önemli bir faktör olarak karşımıza çıkmaktadır. COVID-19 enfeksiyonunun başlangicinda IL-10 aktivitesinin engellenebilmesi için nötralize edici bir antikor kullanılmasının, immün aktive edici etkilerinin sınırlandırılabilmesi bakımından önemli olabileceği düşünülmektedir. COVID-19 enfeksiyonunun patogenezinde ve tedavisinin belirlenmesinde sistemik olarak artmış IL-10'un rolünü belirleyebilmek için kapsamlı çalışmalara ihtiyaç duyulmaktadır ${ }^{37}$.

\section{COVID-19 Komplikasyonu ARDS Fizyopatolojisi:}

COVID-19 enfeksiyonunun ilk aşamalarında akciğer hasarı pulmoner vasküler bozukluk ile ilişkilendirilmiştir. ARDS tanısı ve tedavisi hakkında farklı görüşler bildirilmiştir. ARDS genellikle akciğerlerde gaz değişim kısıtlamasına ve sıvı birikmesine neden olabilen ve böylece sistemik hipoksiye yol açabilen ciddi bir hasar ile karakterizedir. ARDS hastalarında taşipne ve siyanoz ile birlikte nefes darlığ 1 da görülmektedir. $\mathrm{Bu}$ yüzden ARDS gelişen hastalarda kalp ve beyin gibi organların düzgün çalışması etkilenebilmektedir ${ }^{4}$.

ARDS'nin L (Low) ve H (High) fenotipleri olmak üzere iki grupta sınıflandırıldığı bildirilmiştir. $\mathrm{Bu}$ sinıflandırmanın, ARDS patofizyolojisinin daha iyi anlaşılabilmesi ve bu fenotiplere göre farklı terapötik stratejilerin geliştirilebilmesi açısından önemli olduğu düşünülmektedir ${ }^{45,46}$

ARDS'de L fenotipi erken aşamalarda ortaya çıkan, subplevral interstisyum ile sinırlı hafif bir inflamasyon ile karakterize olan fenotiptir ${ }^{47}$. Bu fenotipte akciğerlerde homojen olmayan alanlarda farklı elastik özellikler ve ara sira konsolidasyon ile birlikte buzlu cam görünümleri gözlenmektedir. Nominal kompliyans ve düşük akciğer ağırlığı ile karakterize olan L tipi fenotipte düşük elastans gözlenmektedir. Pulmoner vasküler düzensizlik, endotel hücrelerinin ve arteriyel düz kas hücrelerinin yüzeylerinde bulunan ACE 2 reseptörüne SARS-CoV-2 afinitesi ile ilişkilendirilmiştir ${ }^{4}$.

COVID-19 enfeksiyonunun düz kas kasılması kaybına yol açarak zayıf hipoksik vazokonstriksiyona ve akciğerlerin bazı bölgelerinde düşük vasküler dirence neden olabileceği düşünülmektedir ${ }^{48}$. Viral replikasyon sonucunda epitelde ve endotelde hücresel hasara yol açabilecek proinflamatuar sitokinler salgılanmaktadır. Doğuştan gelen immün sistemin aşırı aktivasyonu ve sitokin firtınası mikrovasküler sistemde önemli hasar gelişimi ile ilişkilendirilmiştir ${ }^{4,50}$. Ayrıca COVID-19 enfeksiyonundan kaynaklanan trombozun 
sistemik bir hiperkoagulasyon tarafindan tetiklenmesi alveoler birimlere kan akışının engellenmesine neden olabilen birçok mikrotrombin oluşumuna yol açmak$\operatorname{tad}_{10}{ }^{51,52}$. Yoğun bakım ünitelerinde tedavi gören hastaların yaklaşık \%20-\%30 kadarında azalmış bölgesel akciğer kompliyansı ile karakterize olan ARDS gelişmektedir. Böylece azalmış ventilatuar yanıt ve zayıf oksijenasyon ortaya çıkmaktadır ${ }^{4}$.

ARDS'nin H fenotipi hipoksemi, azalmış pulmoner kompliyans, bilateral akciğer infiltratları ile karakterizedir $^{53}$. SARS-CoV-2 yapisinda bulunan spike proteini olarak adlandırılan S proteini ACE 2 reseptörüne bağlanma yoluyla konakçı hücreye giriş yapılabilmesinde rol olan önemli bir belirleyicidir. ACE 2 reseptörüne bağlanma sonucunda konakçı serin proteaz tip 2 olarak bilinen TMPRSS2, S proteinini böler. Böylece viral ve hücresel membran füzyonu gerçekleşmektedir. SARS-CoV-2'nin replikasyona yardımcı olacak genetik materyali sitoplazmada serbest kalmaktadır. Akciğerlerde Tip II alveoler epitel hüceleri virüs replikasyonunda önemlidir ve virüsün konakçı hücreye girişi sonucunda konakçı immün yanıt tetiklenmektedir. Böylece IL-6, IL-12, IL-17, IL-18, IL-33 gibi proinflamatuar sitokinlerin salınımı indüklenmektedir. $\mathrm{Bu}$ proinflamatuar sitokinler enfeksiyon bölgesinde nötrofilleri ve monositleri toplama yoluyla diğer proinflamatuar sitokinleri ve kemokinleri aktive etmektedir. $\mathrm{Bu}$ şekilde hiperinflamasyon durumu ortaya çıkmakta ve ARDS gelişimi ile ilişsili olarak akciğerlerde doğrudan hasar meydana gelmektedir ${ }^{4}$.

ARDS gelişiminde genetik yatkınlık ve inflamatuar sitokinler de önemli rol oynamaktadırlar. ACE 2 ve IL-10, Tümör Nekroz Faktör (TNF) ve Vasküler Endotel Büyüme Faktörü (VEGF) gibi çeşitli genler arasında anlamlı bir ilişkinin olduğu düşünülmektedir. COVID-19 enfeksiyonunda sitokin firtınası ortaya çıkabilmekte ve ARDS gelişebilmektedir. Önemli sitokinler olarak bilinen IL-6 ve IL-8 plazma düzeylerindeki artışlar, ARDS'nin negatif sonuçları ile ilişkilendirilmiştir. ARDS hastalarında gelişen pulmoner infiltrasyon ve buna bağlı olarak gelişen akciğer hasarı da artmış IL-6 düzeyleri ile ilişkilendirilmiştir. Makrofaj aktivasyon sendromu gelişen hastaların yaklaşık yarısında ARDS sonucunda akciğer hasarı gelişebilmektedir. COVID-19 hastalarında serum C-Reaktif Protein (CRP), laktat dehidrogenaz, kreatinin, kreatin kinaz, ferritin, IL-6 ve D-dimer düzeylerinin arttığ belirlenmiştir ${ }^{1}$.

\section{ARDS ve IL-10 Gen Varyasyonu}

Sepsis ve travma gibi klinik risklere sahip olan hastaların bir bölümünde ARDS gelişebilmektedir. Bireyler arası farklı sonuçlar gösteren genetik varyasyonlar doğuştan gelen immünitede, pulmoner defansta ve inflamatuar yanıtta önemli rol oynamaktadırlar. Çeşitli genetik varyasyonlar ve ARDS, sepsis, pnömoni gelişimi arasında anlamlı ilişkiler olduğu düşünülmektedir.
$\mathrm{Bu}$ genetik varyasyonlar arasında, IL-10 geni gibi sitokin genlerinde ortaya çıkan genetik varyasyonlar bulunmaktadir ${ }^{54}$.

IL-10 önemli bir antiinflamatuar sitokin olarak bilinmektedir. Nitrik oksit sentezinde, inflamatuar hücrelerin apoptozunda ve makrofaj aktivasyonunun bask1lanmasında önemli rol oynayan IL-10, diğer proinflamatuar sitokinlerin modülasyonunda da etkilidir. İnsanlarda dolaşımdaki yüksek IL-10 düzeyleri ve septik şok, yaralanma şiddeti, ölüm oranları arasında anlamlı bir ilişki olduğu bildirilmiştir. ARDS hastalarında yüksek plazma IL-10 düzeyleri ve düşük IL-10 bronkoalveolar lavaj konsantrasyonu artmış mortalite ile ilişkilendirilmiştir ${ }^{54}$.

IL-10 geninde tanımlanan IL-10 (-1082G/A) gen varyasyonu genin promotör bölgesinde -1082 pozisyonunda guanin / adenin baz yer değiştirmesi ile karakterize bir genetik varyasyondur ve bu genetik varyasyon IL-10 düzeylerinin düzenlenmesinde etkilidir. IL-10 (1082G/A) gen varyasyonunun GG homozigot genotipini ve $G$ alelini taşıyan bireylerde in vitro uyarımı takiben dolaşımda daha yüksek IL-10 düzeyleri, daha yüksek IL-10 mRNA ekspresyonu ve buna bağlı olarak daha yüksek IL-10 üretimi belirlenmiştir ${ }^{55-57}$.

ARDS gibi kritik hastalıklarda IL-10 (-1082G/A) gen varyasyonunun GG homozigot genotipi düşük hastalık şiddeti, azalmış hastaneye yatış oranı, organ disfonksiyonu ve mortalite ile ilişkilendirilmiştir ${ }^{58,59}$. ARDS gibi kritik hastalıkların gelişiminde proinflamatuar ve antiinflamatuar yanıtlar arasındaki denge oldukça önemlidir. Pnömoni hastalarında yüksek IL-10 üretimi ile ilişkili olan genotipin daha fazla immunosupresyona yol açabileceği ve bu durumun şiddetli hastalık yükü ile sonuçlanabileceği düşünülmektedir. Yoğun inflamasyon ARDS gibi hastalıkların patogenezinde belirleyici bir özelliktir ve yüksek proinflamatuar durumu olan hastalarda yüksek IL-10 düzeyleri ile ilişkili olan genotiplerin faydalı yönde modüle edici, koruyucu bir etkiye sahip olabileceği de bildirilmiştir. Amerikalı bir popülasyon ile gerçekleştirilmiş çalışmada ARDS olan hastalarda IL-10 (-1082G/A) gen varyasyonunun GG homozigot genotipi daha düşük mortalite ve organ yetmezliği ile ilişkilendirilmiştir. Ancak ARDS ve IL-10 gen varyasyonları, ekspresyon düzeyleri arasındaki ilişkilerin doğrulanabilmesi için farklı popülasyonlar ile gerçekleştirilmiş daha kapsamlı araştırmalara ihtiyaç duyulmaktadır ${ }^{54,60}$.

\section{Sonuç}

SARS-CoV-2'nin neden olduğu COVID-19 enfeksiyonu tüm dünyada küresel bir kriz yaratmıştır. COVID-19 enfeksiyonunun riskinin ve ciddiyetinin düzenlenmesinde etkili olabilecek genetik varyasyonların belirlenmesi önemlidir. Çeşitli etnik gruplarda COVID-19 enfeksiyon oranının belirlenmesinde genetik varyasyonlar gibi genetik risk faktörlerinin rolü ve enfeksiyonun şiddeti arasındaki ilişkinin araştırılması- 


\section{Covid-19 ARDS Komplikasyonu ve IL-10 Gen Varyasyonu}

nı amaçlayan sınırlı sayıda araştırma bulunmaktadır. Solunum yolu enfeksiyonlarına yatkınlıklarda genetik ve kazanılmış risk faktörlerinin birlikte etkili olabileceği düşünülmektedir. Şiddetli COVID-19 enfeksiyonu ve bu enfeksiyonun önemli komplikasyonlarından biri olan ARDS gelişimine yatkınlıkta önemli genetik varyasyonlar gibi prognostik faktörlerin belirlenebilmesi oldukça önemlidir. IL-10 geninde tanımlanan IL10 (-1082G/A) gen varyasyonu gibi sitokin gen varyasyonlarının proinflamatuar ve antiinflamatuar sitokin düzeylerini etkileyebilme yoluyla COVID-19 enfeksiyonu olan hastalarda, hastalığın progresyonunu modüle edebileceği düşünülmektedir. IL-10 geni hücresel ve humoral immünitenin düzenlenmesindeki potansiyel rolü nedeniyle çeşitli otoimmün hastalıkların, inflamatuar hastalıkların, neoplazmaların patofizyolojik mekanizmalarında etkili olabilecek aday bir gen olarak gösterilmektedir. IL-10 geninin promotör bölgesinde ortaya çıkan IL-10 (-1082G/A), IL-10 ($892 \mathrm{C} / \mathrm{T})$ ve IL-10 (-592C/A) gen varyasyonları sonucunda IL-10 mRNA ve protein düzeylerinde değişiklikler saptanmıştır. IL-10 geninde tanımlanan bu genetik varyasyonlar ve COVID-19 komplikasyonlarından biri olan ARDS gibi hastalıklara yatkınlığın altında yatan patolojik süreçler ile ilgili mekanizmalar arasındaki ilişkileri araştırmaya yönelik daha kapsamlı çalışmalar yapılması gerekmektedir. Böylece COVID-19 ile ilişkili ARDS patogenezinde, IL-10'un potansiyel rolüne bağlı olarak hastalık için yeni tedavi yöntemlerinin belirlenebilmesine yönelik stratejilerin geliştirilebilmesi mümkün olabilecektir.

\section{Etik Kurul Onay Bilgisi:}

Çalışma derleme makale olup etik kurul iznine gerek yoktur.

\section{Araștırmacı Katkı Beyanı:}

Fikir ve tasarım: N.A., A.A.; Veri toplama ve işleme: N.A., A.A. Analiz ve verilerin yorumlanması: N.A., A.A.; Makalenin önemli bölümlerinin yazılması: N.A., A.A.

Destek ve Teşekkür Beyanı:

Yazarların destek ve teşekkür beyanı yoktur.

\section{Kaynaklar}

1. Öztürk R, Taşova Y, Ayaz A. COVID-19: pathogenesis, genetic polymorphism, clinical features and laboratory findings. Turk J Med Sci. 2020;50:638-657. doi:10.3906/sag-2005-287.

2. Sungnak $\mathrm{W}$, Huang $\mathrm{N}$, Bécavin $\mathrm{C}$ et al. SARSCoV-2 entry factors are highly expressed in nasal epithelial cells together with innate immune genes. Nature Medicine. 2020;26(5): 681687. doi: 10.1038/s41591-020-0868-6.

3. Ulrich H, Pillat MM. CD147 as a target for COVID-19 treatment: suggested effects of azithromycin and stem cell engagement. Stem Cell Reviews and Reports. 2020;16:434-440. doi: 10.1007/s12015-020-09976-7.

4. Montenegro F, Unigarro L, Paredes $\mathrm{G}$ et al. Acute respiratory distress syndrome (ARDS) caused by the novel coronavirus disease (COVID-19): a practical comprehensive literature review. Expert Rev Respir Med. 2021;15(2):183-195. doi: 10.1080/17476348.2020.1820329.
5. Mulinari Turin de Oliveira N, Fernandes da Silva Figueiredo I, Cristine Malaquias da Silva L et al. Tissue Proteases and Immune Responses: Influencing Factors of COVID-19 Severity and Mortality. Pathogens. 2020;9(10):817. doi: 10.3390 /pathogens9100817.

6. Jin Y, Yang H, Ji W et al. Virology, epidemiology, pathogenesis, and control of COVID-19. Viruses. 2020;12 (4):372. doi: 10.3390/v12040372.

7. Zou X, Chen $\mathrm{K}$, Zou $\mathrm{J}$ et al. The single-cell RNA-seq data analysis on the receptor ACE2 expression reveals the potential risk of different human organs vulnerable toWuhan 2019-nCoV infection. Frontiers in Medicine. 2020;14(2):185-192. doi: 10.1007/s11684-020-0754-0.

8. Xiao F, Tang M, Zheng $\mathrm{X}$ et al. Evidence for gastrointestinal infection of SARS-CoV-2. Gastroenterology. 2020;158(6): 1831-1833.e3. doi: 10.1053/j.gastro.2020.02.055.

9. Zhou Y, Zhang Z, Tian J et al. Risk factors associated with disease progression in a cohort of patients infected with the 2019 novel coronavirus. Annals of Palliative Medicine. 2020;9(2):428-436. doi: 10.21037/apm.2020.03.26.

10. Grasselli G, Zangrillo A, Zanella A et al. Baseline characteristics and outcomes of 1591 patients infected with SARS-CoV-2 admitted to ICUs of the Lombardy Region, Italy. The Journal of the American Medical Association. 2020;323(16):1574-1581. doi: 10.1001/jama.2020.53948.

11. Cheng Y, Luo R, Wang $\mathrm{K}$ et al. Kidney disease is associated with in-hospital death of patients with COVID-19. Kidney International. 2020;97(5):829-838. doi: 10.1016/j.kint. 2020.03.005.

12. Coutard B, Valle C, de Lamballerie $X$ et al. The spike glycoprotein of the new coronavirus $2019-\mathrm{nCoV}$ contains a furin-like cleavage site absent in $\mathrm{CoV}$ of the same clade. Antiviral Res. 2020;176:104742. doi: 10.1016/j.antiviral.2020.104742.

13. Hoffmann M, Kleine-Weber H, Schroeder S et al. SARS-CoV2 Cell entry depends on ACE2 and TMPRSS2 and is blocked by a clinically proven protease inhibitor. Cell. 2020;181(2):271-280.e8. doi: 10.1016/j.cell.2020.02.052.

14. Xu Z, Shi L, Wang Y et al. Pathological findings of COVID-19 associated with acute respiratory distress syndrome. Lancet Respir Med. 2020;8(4):420-422. doi: 10.1016/S22132600(20)30076-X.

15. Wu F, Zhao S, Yu B et al. A new coronavirus associated with human respiratory disease in China. Nature. 2020;579:265-269. doi: 10.1038/s41586-020-2008-3.

16. Qin C, Zhou L, Hu Z et al. Dysregulation of Immune Response in Patients With Coronavirus 2019 (COVID-19) in Wuhan, China. Clin Infect Dis. 2020;28:71(15):762-768. doi: 10.1093/cid/ciaa248.

17. Thevarajan I, Nguyen THO, Koutsakos $M$ et al. Breadth of concomitant immune responses prior to patient recovery: a case report of non-severe COVID-19. Nat Med. 2020;26(4):453-455. doi: 10.1038/s41591-020-0819-2.

18. Zuo Y, Yalavarthi S, Shi H et al. Neutrophil extracellular traps in COVID-19. JCI Insight. 2020;4:5(11):e138999. doi: 10.1172/jci.insight.138999.

19. McFadyen JD, Stevens H, Peter K. The Emerging Threat of (Micro) Thrombosis in COVID-19 and Its Therapeutic Implications. Circ Res. 2020;31:127(4):571-587. doi: 10.1161/CIRCRESAHA.120.317447.

20. Guo YR, Cao QD, Hong ZS et al. The origin, transmission and clinical therapies on coronavirus disease 2019 (COVID-19) outbreak - an update on the status. Mil Med Res. 2020;13:7(1):11. doi: 10.1186/s40779-020-00240-0.

21. Inciardi RM, Lupi L, Zaccone $\mathrm{G}$ et al. Cardiac Involvement in a Patient With Coronavirus Disease 2019 (COVID-19). JAMA Cardiol. 2020;5(7):819-824. doi: 10.1001/jamacardio. 2020.1096 . 
22. Shi S, Qin M, Shen B et al. Association of Cardiac Injury With Mortality in Hospitalized Patients With COVID-19 in Wuhan, China. JAMA Cardiol. 2020;5(7):802-810. doi: 10.1001/jamacardio.2020.0950.

23. Wang $\mathrm{D}, \mathrm{Hu} \mathrm{B}, \mathrm{Hu} \mathrm{C}$ et al. Clinical Characteristics of 138 Hospitalized Patients With 2019 Novel Coronavirus-Infected Pneumonia in Wuhan, China. JAMA. 2020;323(11):1061-1069. doi: 10.1001/jama.2020.1585.

24. Yang X, Yu Y, Xu J et al. Clinical course and outcomes of critically ill patients with SARS-CoV-2 pneumonia in Wuhan, China: a single-centered, retrospective, observational study. Lancet Respir Med. 2020;8(5):475-481. doi: 10.1016/S22132600(20)30079-5.

25. Jin X, Lian JS, Hu JH et al. Epidemiological, clinical and virological characteristics of 74 cases of coronavirus-infected disease 2019 (COVID-19) with gastrointestinal symptoms. Gut. 2020;69(6):1002-1009. doi: 10.1136/gutjnl-2020-320926.

26. Lin L, Jiang X, Zhang Z et al. Gastrointestinal symptoms of 95 cases with SARS-CoV-2 infection. Gut. 2020;69:997-1001. doi:10.1136/gutjnl-2020-321013.

27. Tian Y, Rong L, Nian W et al. Review article: gastrointestina features in COVID-19 and the possibility of faecal transmission. Aliment Pharmacol Ther. 2020;51(9):843-851. doi: 10.1111/apt.15731

28. Bello RO, Chin VK, Abd Rachman Isnadi MF et al. The Role, Involvement and Function(s) of Interleukin-35 and Interleukin37 in Disease Pathogenesis. Int J Mol Sci. 2018;19(4):1149. doi: 10.3390/ijms19041149.

29. Gastl GA, Abrams JS, Nanus DM et al. Interleukin-10 production by human carcinoma cell lines and its relationship to interleukin-6 expression. Int J Cancer. 1993;55(1):96-101. doi 10.1002/ijc.2910550118.

30. Pisa P, Halapi E, Pisa EK et al. Selective expression of interleukin 10, interferon gamma, and granulocyte-macrophage colony-stimulating factor in ovarian cancer biopsies. Proc Natl Acad Sci U S A. 1992;89(16):7708-7712. doi 10.1073/pnas.89.16.7708.

31. Spits $H$, de Waal Malefyt R. Functional characterization of human IL-10. Int Arch Allergy Immunol. 1992;99(1):8-15. doi: $10.1159 / 000236329$.

32. Eskdale J, Gallagher G. A polymorphic dinucleotide repeat in the human IL-10 promoter. Immunogenetics. 1995;42(5):444445. doi: 10.1007/BF00179416.

33. Eskdale J, Kube D, Gallagher G. A second polymorphic dinucleotide repeat in the $5^{\prime}$ flanking region of the human IL10 gene. Immunogenetics. 1996;45(1):82-83. doi 10.1007/s002510050174.

34. Pandey M, Awasthi S, Singh U et al. Association of IL-10 Gene Polymorphism $(-819 \mathrm{C}>\mathrm{T},-592 \mathrm{C}>\mathrm{A}$ and $-1082 \mathrm{G}>\mathrm{A})$ with Preterm Birth. Indian J Pediatr. 2018;85(2):93-101. doi: 10.1007/s12098-017-2496-9.

35. Al-shehmany AS, El-Kafoury AA., Haroun MA et al. Contribution of IL-10 (SNP -819 C/T and SNP-1082 G/A) polymorphisms variants to the risk of type 1 diabetes in Egyptian population. Iraqi Journal of Biotechnology. 2014;13(1):54-60.

36. Castelli V, Cimini A, Ferri C. Cytokine Storm in COVID-19: "When You Come Out of the Storm, You Won't Be the Same Person Who Walked in". Front Immunol. 2020;11:2132. doi 10.3389/fimmu.2020.02132.

37. Lu L, Zhang H, Dauphars DJ et al. A Potential Role of Interleukin 10 in COVID-19 Pathogenesis. Trends Immunol. 2021;42(1):3-5. doi: 10.1016/j.it.2020.10.012.

38. Dhar SK, Vishnupriyan K, Damodar S et al. IL-6 and IL-10 as predictors of disease severity in COVID-19 patients: results from meta-analysis and regression. Heliyon. 2021;7(2):e06155. doi: 10.1016/j.heliyon.2021.e06155.
39. Zhao Y, Qin L, Zhang P et al. Longitudinal COVID-19 profiling associates IL-1RA and IL-10 with disease severity and RANTES with mild disease. JCI Insight. 2020;5(13):e139834. doi: 10.1172/jci.insight.139834.

40. Diao B, Wang C, Tan Y et al. Reduction and Functional Exhaustion of T Cells in Patients With Coronavirus Disease 2019 (COVID-19). Front Immunol. 2020;11:827. doi: 10.3389/fimmu.2020.00827.

41. Hu WC. Use interleukin- 10 as the therapeutic agent for COVID-19. OSFPREPRINTS. 2020 doi: 10.31219/osf.io/arfhb.

42. Lu L, Zhang $\mathrm{H}$, Zhan $\mathrm{M}$ et al. Preventing Mortality in COVID19 Patients: Which Cytokine to Target in a Raging Storm? Front Cell Dev Biol. 2020;8:677. doi:10.3389/fcell.2020.00677.

43. Lauw FN, Pajkrt D, Hack CE et al. Proinflammatory effects of IL-10 during human endotoxemia. Journal of Immunology. 2000;165(5):2783-2789. doi: 10.4049/jimmunol.165.5.2783.

44. Li H, Liu L, Zhang D et al. SARS-CoV-2 and viral sepsis: observations and hypotheses. Lancet. 2020;395(10235):15171520. doi: 10.1016/S0140-6736(20)30920-X.

45. Potus F, Mai V, Lebret M et al. Novel insights on the pulmonary vascular consequences of COVID-19. Am J Physiol Lung Cell Mol Physiol. 2020;319(2):L277-L288. doi: 10.1152/ajplung.00195.2020.

46. Gattinoni L, Chiumello D, Caironi P et al. COVID-19 pneumonia: different respiratory treatments for different phenotypes? Intensive Care Med. 2020;46(6):1099-1102. doi: 10.1007/s00134-020-06033-2.

47. Song YG, Shin HS. COVID-19, A Clinical Syndrome Manifesting as Hypersensitivity Pneumonitis. Infect Chemother. 2020;52(1):110-112. doi: 10.3947/ic.2020.52.1.110.

48. Gattinoni L, Chiumello D, Rossi S. COVID-19 pneumonia: ARDS or not? Crit Care. 2020;24(1):154. doi: 10.1186/s13054020-02880-z.

49. Conti P, Ronconi G, Caraffa A et al. Induction of proinflammatory cytokines (IL-1 and IL-6) and lung inflammation by Coronavirus-19 (COVI-19 or SARS-CoV-2): antiinflammatory strategies. J Biol Regul Homeost Agents. 2020;34(2):327-331. doi: 10.23812/CONTI-E.

50. Garg S, Garg M, Prabhakar N et al. Unraveling the mystery of Covid-19 cytokine storm: from skin to organ systems. Dermatologic Therapy. 2020;33:e13859. doi: 10.1111/dth.13859.

51. Ciceri F, Beretta L, Scandroglio AM et al. Microvascular COVID-19 lung vessels obstructive thromboinflammatory syndrome (MicroCLOTS): an atypical acute respiratory distress syndrome working hypothesis. Crit Care Resusc. 2020;22(2):95-97.

52. Cressoni M, Caironi P, Polli F et al. Anatomical and functional intrapulmonary shunt in acute respiratory distress syndrome. Crit Care Med. 2008;36(3):669-675. doi: 10.1097/01.CCM.0000300276.12074.E1.

53. Jain A, Doyle DJ. Stages or phenotypes? A critical look at COVID-19 pathophysiology. Intensive Care Med. 2020;46(7):1494-1495. doi: 10.1007/s00134-020-06083-6.

54. Gong MN, Thompson BT, Williams PL et al. Interleukin-10 polymorphism in position -1082 and acute respiratory distress syndrome. Eur Respir J. 2006;27(4):674-681. doi: 10.1183/09031936.06.00046405.

55. Turner DM, Williams DM, Sankaran D et al. An investigation of polymorphism in the interleukin-10 gene promoter. Eur $\mathrm{J}$ Immunogenet. 1997;24(1):1-8. doi: 10.1111/j.13652370.1997.tb00001.x

56. Suárez A, Castro P, Alonso R, Mozo L, Gutiérrez C. Interindividual variations in constitutive interleukin-10 messenger RNA and protein levels and their association with genetic polymorphisms. Transplantation. 2003;75(5):711-717. doi: 10.1097/01.TP.0000055216.19866.9A. 


\section{Covid-19 ARDS Komplikasyonu ve IL-10 Gen Varyasyonu}

57. Galley HF, Lowe PR, Carmichael RL et al. Genotype and interleukin-10 responses after cardiopulmonary bypass. Br J Anaesth. 2003;91(3):424-426. doi: 10.1093/bja/aeg174.

58. Gallagher PM, Lowe G, Fitzgerald T et al. Association of IL-10 polymorphism with severity of illness in community acquired pneumonia. Thorax. 2003;58(2):154-156. doi: 10.1136/thorax.58.2.154.

59. Schaaf BM, Boehmke F, Esnaashari H et al. Pneumococcal septic shock is associated with the interleukin-10-1082 gene promoter polymorphism. Am J Respir Crit Care Med. 2003;168(4):476-80. doi: 10.1164/rccm.200210-1164OC.

60. Ghafouri-Fard S, Noroozi R, Vafaee R et al. Effects of host genetic variations on response to, susceptibility and severity of respiratory infections. Biomed Pharmacother. 2020;128:110296. doi: 10.1016/j.biopha.2020.110296. 
N. Alkanlı ve A. Ay 